\title{
Afforestation in Response to Thermal Change in the Forest-Savannah Transition of the Lamto Scientific Reserve, Côte d'Ivoire
}

\author{
Kouakou Guy-Casimir Douffi ${ }^{* * i D}$, Akoua Clémentine Yao ${ }^{1,2}$ (iD), Kouao Jean Koffi ${ }^{1}$, Amara \\ Sidiki Traoré1 ${ }^{(i D}$, Moussa Koné ${ }^{1}$ (D)
}

${ }^{1}$ UFR Sciences de la Nature, Pôle de Recherche Environnement et Développement Durable, Université Nangui Abrogoua, 02 BP 801 Abidjan 02, Côte d'Ivoire

${ }^{2}$ Centre Suisse de Recherches Scientifiques en Côte d'Ivoire (CSRS), 01 BP 1303 Abidjan 01

\begin{abstract}
In a context of deforestation and climate change, the land cover or use induced by human or natural transformation influences the climate from global to local scale. The aim of this study was to assess the vegetation dynamic between 1985 and 2020 within the Lamto Scientific Reserve (Côte d'Ivoire). After mapping the land cover by the neural network algorithm for the years 1988, 2002 and 2020, the climatic parameters including the Land Surface Temperature (LST) and the standardized precipitation index (SPI) were estimated since 1985. Then, the land cover response was estimated in the presence of the LST, with the average LST from 1985 to 2020 as a threshold. The forest dynamic showed an increase in area of 291.87 ha in 32 years. The area of forest has increased from 610.42 ha (21.42\%) in 1988 to 902.29 ha $(31.59 \%)$ in 2020 . The practice of fire remains predominant in the reserve management. SPI shows three alternating seasons over the time. One wet season (1995 to 2010) framed by two dry seasons (1985 to 1994 and 2011 to 2020). The relation LST -NDVI shows covariation. LST indicates a variation from $30.46^{\circ} \mathrm{C}$ to $34.68^{\circ} \mathrm{C}$, with an increase of $4.22^{\circ} \mathrm{C}$ between 1985 and 2020 . The land cover response indicates that, with the exception of the LST of shrub savannahs and burnt areas, the land cover LST of 1988 and 2002 have remained below the LST threshold $\left(32.70^{\circ} \mathrm{C}\right)$. The land cover LST of 2020 has risen above the threshold. Land-use changes have led to afforestation despite warming due to bushfires. In addition, forests could continue to act as a thermal moderator of Lamto reserve.
\end{abstract}

Keywords: Deforestation, Thermal change, Forest-Savannah Transition, Lamto reserve, Ivory Coast

\section{Introduction}

Phenological change and variation have become increasingly relevant topics in the science of global change. This change is due to the identification of their importance for the functioning of savannahs ecosystems (1/8 of the global land surface) and biogeophysical processes (Gessner et al., 2015). According to Gessner et al. (2015), phenological characteristics in West African savannahs are influenced by land use and bushfires, in addition to climate variability. The availability of time series of remote sensing data offers the possibility to assess the dynamics of its savannah ecosystems. Thermal infrared remote sensing technology has become one of the important means to study the thermal characteristic of the surface (Buyadi et al., 2013; Morshed et al., 2020). Land Surface Temperature (LST) refers to the contact temperature of the earth and is determined using satellite sensors. It is an important parameter relating to interactions with the atmosphere (USGS, 2014). The increased application of thermal remote sensing data in recent years has been a key factor in the launch of the
Landsat 8 TIRS (Thermal InfraRed Sensor), ensuring the continuity of the Landsat observing mission. Many researchers have studied the possibility of assessing and monitoring catastrophic phenomena of the earth, atmosphere and oceans, using Landsat thermal reflection. Land Surface Temperature (LST) plays a key role in various scientific studies. These include management of the ecological environment of plants (Setturu et al., 2013; Douffi et al., 2018), quantification of vegetation index (Sekertekin et al., 2015; Anbazhagan and Paramasivam, 2016). Agriculture and bushfires (Vlassova and Pérez-Cabello, 2016), urban vegetation management (Mobio et al., 2017; Odindi et al., 2020) and meteorological and climate studies (Tomlinson et al., 2011) use LST as a methodological support. The characterisation of climatic factors has been possible through the detection of plant moisture related to thermal radiation (Buyadi et al., 2013). Extreme Earth system processes have continued to manifest themselves, particularly in terms of natural hazards whose impacts are felt across the globe with particularly adverse 
consequences for humanity. Drought is one of the major environmental phenomena that has caused millions of deaths and hundreds of billions of dollars in damage. Satellite data has played an increasingly important role in monitoring drought conditions in relation to vegetation. Because of the close relationship between vegetation vigor and available soil moisture, particularly in arid and semi-arid areas, the Normalized Difference Vegetation Index (NDVI) and LST have been used to assess drought conditions.

The increase in LST has negative effects on vegetation, block glaciers and causes climatic changes such as the modification of climatic conditions in monsoon countries by unpredictable rainfall (GIEC, 2014). The regional balance of variability of burnt areas, in relation to rainfall and large-scale climate indices, has been reported over the West African savannahs (N'Datchoh et al., 2015). Côte d'Ivoire in general and the center in particular, is not immune to this climatic variability (Kouamé et al., 2019). The effect of climate combined with anthropogenic factors contributes to environmental change including land use in West Africa (Barnieh et al., 2020). Due to urbanization (anthropogenic activity) of land use, land surface temperature (LST) is increasingly changing (Aik et al., 2020). The LST has also been used to estimate the effect of post-fire wood management strategies on vegetation recovery (Vlassova and Pérez-Cabello, 2016). Urbanization has been identified as a major threat to the environment as it increases demand for urban spaces and transforms natural landscapes on impervious surfaces. This leads to urban warming (Mobio et al., 2017; Odindi et al., 2020). Natural landscapes such as vegetation and water act as thermal sinks that absorb heat. However, thermal emission results in temperature inversion compromised human health, pollution, species loss, high energy consumption and climate change at local, regional and global scales (Odindi et al., 2020). The change in land use at the expense of forests is the reason leading a the increase in the earth's surface temperature (Haylemariyam, 2018; Morshed et al., 2020). This change alters the energy balance of the natural and urban environment.

However, the years 1983 to 2012 have been cited as the hottest period in the Northern Hemisphere in the last 1400 years and projections indicate an increase in land surface temperature during the 21st century (GIEC, 2014). In West Africa, temperature increases over the past 50 years have been recorded, from $0.16^{\circ} \mathrm{C}$ to $0.28^{\circ} \mathrm{C}$ per decade (Barry et al., 2018), with decreasing precipitation (GIEC, 2014).

The aim of this study is to evaluate, in a context of climatic variability coupled with deforestation, the dynamics of vegetation index between 1985 and 2020 in the Lamto Scientific Reserve, located in central Côte
d'Ivoire. The first step was to map the land cover in 1988, 2002 and 2020, and the second was to analyse the dynamics of land cover in response to the land surface temperature of the Lamto Scientific Reserve between 1985 and 2020.

\section{Material and Methods \\ 2.1. Materials \\ 2.1.1. Study Area}

The Lamto Scientific Reserve is located in central Côte d'Ivoire (Figure 1), in the pre-forest sector of the forest-savannah transition zone. This area was chosen for its role in the study of biodiversity and the functioning of the savannah. It is located between the northern latitudes $6^{\circ} 10^{\prime} 53^{\prime \prime}$ and $6^{\circ} 15^{\prime} 20^{\prime \prime}$ and between the western longitudes $4^{\circ} 58^{\prime} 42^{\prime \prime}$ and $5^{\circ} 2^{\prime} 53^{\prime \prime}$, about $180 \mathrm{~km}$ northwest of Abidjan. It covers an area of 2617 ha (OIPR, 2021). The average temperature is $27.96 \pm$ $0.43^{\circ} \mathrm{C}$ and average monthly rainfall is $100.24 \pm 15.34$ $\mathrm{mm}$ (Lamto Station: 1985 to 2019). Lamto is drained by the Bandama River in the North West. The practice of fire helps to maintain the savannahs or delay the progression of the forest (N'Dri et al., 2012). Fire is lit in the region every year during the dry season. Three fire regimes are practiced by researchers, including early (December), mid-season (January) and late (April) fires.

\subsubsection{Satellite and Meteorological Data}

Landsat data were used because of their long coverage of the earth and the continuity of the data. Landsat is equipped with thermal infrared probes that detect electromagnetic radiation. These Landsat data are available at http://earthexplorer.usgs.gov. Table 1 shows the 15 scenes used and acquired in the dry season. These are TM (Thematic Mapper), ETM+ (Enhanced Thematic Mapper plus) and OLI+/TIRS (Operational Land Imager Plus / Thermal Infrared Sensor) sensors that were used for mapping and biogeophysical characterization of Lamto respectively. In addition to the Landsat images, meteorological data (1985 to 2019) from the Lamto Geophysical Station were acquired. These data were used as ground truth for the study of land surface temperature and precipitation data. The choice of this period of study fits in after drought crisis of 1982 - 1983, marked by one season dries particularly prolonged and which influenced the crop year.

\subsubsection{Software and Documentation Sources}

Software used are: QGIS 2.14-Essen for downloading the pyQGIS extension of Land Surface Temperature (LST); ENVI 5.1, for digital image processing and bands ratio calculation using Band math. ArcGIS 10 is used for map editing and raster statistics integrated in Geographical Information System; Microsoft Excel 2013 and Statistica 7.1, for alphanumeric processing. 


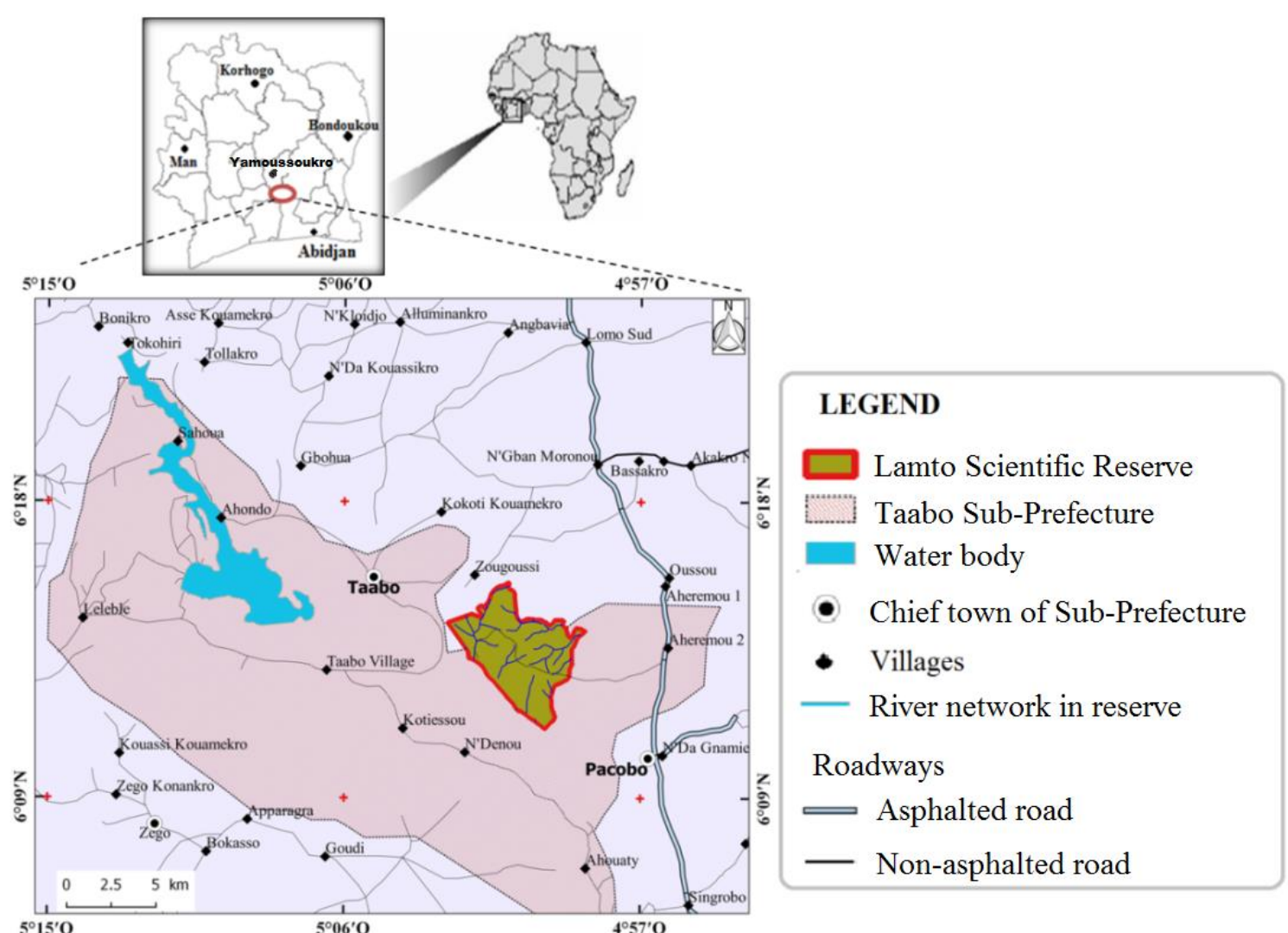

Figure 1. Localization of the scientific reserve of Lamto (Douffi, 2020).

Table 1. Remote sensing data used for the study

\begin{tabular}{|c|c|c|c|c|}
\hline Sensors & Dates & Hours (UTC) & Wavelength & Path / Row \\
\hline TM 5 & April 22, 1985 & $10: 04: 33$ & B6: $0.1-12.5$ & \\
\hline TM 4 & December 22, 1987 & $09: 56: 48$ & B6 : $10.1-12.5$ & \\
\hline TM 4 & December 24, 1988 & $10: 06: 12$ & B6 : $10.1-12.5$ & \\
\hline TM 4 & December 30, 1990 & 09:59:00 & B6 : $10.1-12.5$ & \\
\hline TM 5 & March 15, 1998 & $10: 10: 50$ & B6 : $10.1-12.5$ & \\
\hline TM5 & February 14, 1999 & $10: 13: 28$ & B6 : $10.1-12.5$ & \\
\hline ETM+7 & April 13, 2000 & $10: 26: 33$ & B6 : $10.1-12.5$ & \\
\hline ETM+7 & December 12, 2001 & $10: 22: 53$ & B6 : $10.1-12.5$ & $196-056$ \\
\hline ETM+7 & December 31, 2002 & $10: 22: 34$ & B6 : $10.1-12.5$ & \\
\hline $\mathrm{OLI}+8$ & 12 avril 2014 & $10: 34: 16$ & B10 : $10.1-12.5$ & \\
\hline OLI + 8 & December 27, 2015 & $10: 34: 22$ & B10 : $10.1-12.5$ & \\
\hline OLI + 8 & December 29, 2016 & $10: 34: 28$ & B10 : $10.1-12.5$ & \\
\hline OLI + 8 & January 14, 2017 & $10: 34: 24$ & B10 : $10.1-12.5$ & \\
\hline OLI + 8 & May 12, 2019 & 10:33:46. & B10 : $10.1-12.5$ & \\
\hline $\mathrm{OLI}+8$ & January 07,2020 & $10: 34: 26$ & B10 : $10.1-12.5$ & \\
\hline
\end{tabular}

\subsection{Satellite and Meteorological Data}

Landsat data were used because of their long coverage of the earth and the continuity of the data. Landsat is equipped with thermal infrared probes that detect electromagnetic radiation. These Landsat data are available at http://earthexplorer.usgs.gov. Table 1 shows the 15 scenes used and acquired in the dry season. These are TM (Thematic Mapper), ETM+ (Enhanced Thematic Mapper plus) and OLI+/TIRS (Operational Land Imager Plus / Thermal Infrared Sensor) sensors that were used for mapping and biogeophysical characterization of Lamto respectively. In addition to the Landsat images, meteorological data (1985 to 2019) from the Lamto Geophysical Station were acquired.
These data were used as ground truth for the study of land surface temperature and precipitation data. The choice of this period of study fits in after drought crisis of 1982 - 1983, marked by one season dries particularly prolonged and which influenced the crop year.

\subsection{Software and Documentation Sources}

Software used are: QGIS 2.14-Essen for downloading the pyQGIS extension of Land Surface Temperature (LST); ENVI 5.1, for digital image processing and bands ratio calculation using Band math. ArcGIS 10 is used for map editing and raster statistics integrated in Geographical Information System; Microsoft Excel 2013 and Statistical 7.1, for alphanumeric processing. 


\subsection{Methods}

\subsubsection{Land Use Mapping Using Neural Network} Algorithm

Supervised classification consists of grouping pixels according to their spectral signature. The non-parametric neural network algorithm has been used among many others, for its accommodation to auxiliary data, its flexibility, but also, for its low dependence on training (Hepner, 1990; Jofack Sokeng et al., 2016; Douffi et al., 2019). Several parameters related to the accuracy of backpropagation classification have been defined. Indeed, the six input band classification of 1988, 2002 and 2020 was considered, respectively of the TM and ETM $(3 \mathrm{R}, 7 \mathrm{~B}, 4 \mathrm{~V})$ and $\mathrm{OLI}+(4 \mathrm{R}, 7 \mathrm{~B}, 5 \mathrm{~V})$ color composition by choosing seven output layers: (1) closed forest and gallery forest, (2) Chromolaena odorata bush, (3) wooded savannah; (4) shrub savannah, (5) grassy savannah, barren land and habitats, (6) burnt area and, (7) water. Assessment of the mapping result was possible using the confusion matrix from 33 survey sites (Ground control point, not used for the 66 training data), generating overall accuracies and Kappa at the 0.5 threshold (Pontius, 2000).

\section{Seasonality analysis}

As the notion of drought is relative, any analysis of a precipitation deficit must refer to the activity under study, which is linked to precipitation (GIEC, 2014). In order to obtain seasonality breakdown (dry or wet) on a long time scale, 1985 - 2020 (35 years), one of the most widely used drought indicators was chosen: Standardized Precipitation Index (SPI). The SPI was developed by McKee et al (1993), to determine rainfall deficits. It is based on actual rainfall statistics and consists of calculating the water available in each year, taking into account the rainfall of previous years. The SPI is formulated as follows (Mckee et al., 1993):

$$
S P I=\frac{1}{N_{i}} \sum_{j=1}^{N_{i}} \frac{P_{j}{ }^{i}-\bar{P}_{j}}{\sigma_{j}}
$$

$P_{j}{ }^{i}=$ the rainfall of year $i ; \bar{P}_{j}=$ the average rainfall of the series over the period considered; $\sigma_{j}=$ the standard deviation over the time scale considered; $N_{i}=$ the number of stations in year $i$. The interpretation of the SPI is recorded in Table 2 below.

Table 2. Probability of occurrence of the climatic categories according to Mckee et al. (1993)

\begin{tabular}{ll}
\hline Value of the SPI Index & Precipitation regime \\
\hline SPI $>2$ & Extremely wet \\
from 1.5 to 1.99 & Very wet \\
from 1 to 1.49 & Wet \\
\hline from -0.99 to 0.99 & Normal \\
\hline from -1.00 to -1.49 & Moderately dry \\
from -1.5 to -1.99 & Very dry \\
SPI $<-2$ & Extremely dry \\
\hline
\end{tabular}

\subsubsection{Determination and Analysis of Land Surface Temperature}

Several computer programs for the Land Surface Temperature Calculator (LST Calculator) have been developed (Oguz, 2013; Ndossi and Avdan, 2016). The determination of the land surface temperature (LST) was done in three steps on image data from 1985 to 2020. The first step is the brightness temperature (TB), the second step is the surface emissivity (LSE) and the third step is the LST. The calculation was performed in the pyGis extension containing the Land Surface Temperature algorithm (Ndossi and Avdan, 2016).

\section{Estimation of the brightness temperature (TB)}

The thermal bands are composed of digital pixel values (Digital Number, DN). These digital values are converted to atmospheric spectral radiance during radiometric calibration. The Offset Calibration Factor for Landsat 8 images has been set to -0.29 (USGS, 2014). Although Landsat 8 TIRS has two thermal infrared bands, only band 10 data are suitable for use in LST retrieval at present due to the uncertainty in band 11 values (Barsi et al., 2014). Furthermore, the ETM+ probe is used in Low Gain. After the calibration, the conversion of the raster image of the atmospheric spectral radiance into brightness temperature (TB) was performed. This conversion comes from the following reformulated Planck equation (USGS, 2014):

$T B=[K 2 / \ln (K 1 / L \lambda+1)]-273.15$

$T B$ is the temperature expressed in degrees Kelvin $(K), K 1$ and $K 2$ vary with wavelength and sensor, $L \lambda$ is atmospheric spectral radiance ( $W \mathrm{~m}-2 \mu \mathrm{m}-1 \mathrm{sr}-1)$.

\section{Land Surface Emissivity (LSE)}

The determination of surface emissivity (Zhang et al., 2006) requires the thresholding of the Normalized Difference Vegetation Index (NDVI). NDVI is sensitive to biomass and chlorophyll activity and varies between 1 and +1 . If the vegetation cover is more developed and healthy, higher will be the NDVI, with high Near Infrared (PIR) and weak Red (R) value. If the vegetation is dead or the data was recorded on bare ground, the $\mathrm{R}$ will be lower and the PIR will be higher, which will decrease the Near Infrared-Red difference and the corresponding NDVI. It is expressed as follows:

$$
N D V I=(R-P I R) /(R-P I R)
$$

The algorithm of Zhang et al. (2006) was applied in the determination of the LSE. The NDVI thresholding is summarized in Table 3. 
Table 3. Thresholding of the NDVI according to Zhang et al. (2006) algorithm

\begin{tabular}{ll}
\hline NDVI & LSE \\
\hline NDVI $<0.185$ & 0.995 \\
$0.185<$ NDVI $<0.157$ & 0.985 \\
$0.157<$ NDVI $<0.727$ & $1.009+0.047 \ln ($ NDVI) \\
NDVI $>0.727$ & 0.990 \\
\hline
\end{tabular}

\subsubsection{Land Surface Temperature (LST)}

Obtaining the Land surface temperature requires two parameters, namely, the brightness temperature (TB), the surface emissivity (LSE) and constants including the atmospheric transmittance (T0) and the mean effective atmospheric temperature (Ta). For this purpose, the mono window algorithm (MWA) was used. For the LANDSAT TM, ETM+ and OLI 8 /TIRS sensors, the mono-window algorithm was used and is as follows (Qin et al., 2001; Ndossi and Avdan, 2016):

$L S T=\left[a_{i}\left(1-C_{i}-D_{i}\right)+\left(b_{i}\left(1-C_{i}-D_{i}\right)+\right.\right.$ $\left.\left.C_{i}+D_{i}\right) \times T B-D_{i} \times T_{a}\right] / C_{i}$

$T B$ is the brightness temperature (Equation 1), $T a$ is the mean effective atmospheric temperature. The constants $C i$ and $D i$ are given in Table 4.

Table 4. Parameters of LST calculation in the thermal channel of Landsat

\begin{tabular}{|c|c|c|}
\hline Relationship & Definition & Authors cited \\
\hline $\begin{array}{c}a_{i}=-67.355351 \\
b_{i}=0.458606\end{array}$ & $a_{i}$ et $b_{i}=$ constants of the algorithm & $\begin{array}{c}\text { Buyadi et al. (2013) } \\
\text { Şekertekin et al. (2015) }\end{array}$ \\
\hline $\begin{aligned} \mathrm{Ta} & =17.9769+0.91715 \mathrm{~T}_{0} . \text { avec } \\
\mathrm{T}_{0} & =302.55 \mathrm{~K} . \text { in tropical area }\end{aligned}$ & $\begin{array}{c}\mathrm{Ta}=\text { mean effective atmospheric } \\
\text { temperature }\end{array}$ & $\begin{array}{c}\text { Şekertekin et al. (2015) } \\
\text { Qin et al. (2001) }\end{array}$ \\
\hline $\begin{array}{c}\mathrm{Ci}=\varepsilon \mathrm{i} \times \tau \mathrm{i} \\
\mathrm{Di}=(1-\tau \mathrm{i})[1+(1-\varepsilon \mathrm{i}) \times \tau \mathrm{i}] \\
\text { Avec. } \\
\tau \mathrm{i}=0.974290-0.08007 \times \mathrm{W} \\
\varepsilon \mathrm{i}=0.004 \mathrm{Pv}+0.986\end{array}$ & $\begin{array}{c}\tau \mathrm{i}=\text { atmospheric transmittance } \\
\varepsilon \mathrm{i}=\text { emissivity of the earth's surface } \\
\mathrm{W}(\text { atmospheric water vapour })=3.25 \\
\left.\mathrm{~g} / \mathrm{Cm}^{2}\right)\end{array}$ & $\begin{array}{l}\text { FLAASH Correction } \\
\text { Report (Douffi, 2020) }\end{array}$ \\
\hline TB & $\mathrm{TB}=$ brightness temperature $\left({ }^{\circ} \mathrm{K}\right)$ & Qin et al. (2001) \\
\hline
\end{tabular}

\section{Results}

\subsection{Characterization and Dynamics of Lamto Land Use}

The land cover characterization was successfully achieved with Kappa coefficients and overall accuracies above $80 \%$. Comparative analysis of land cover in Lamto shows that the area of forest formations increased from 610.42 ha $(21.42 \%)$ in 1988 to 662.17 ha $(23.24 \%)$ and 902.29 ha $(31.59 \%)$ in 2002 and 2020 respectively (Table 5). The current trend is an increase of 291.87 ha in 32 years (1988 to 2020). Fire activation (Fx) remains a predominant practice within the Lamto reserve (Figure 2).
3.2. Characterization and Dynamics of Lamto Temperature and Precipitation

Temporal evolution of Land Surface Temperature from 1985 and 2020

The land surface temperature (LST) of the Lamto reserve shows a trend (Figure 3). It increases significantly over time (beta $=0.536, p=0.039)$. Over the period 1985 to 2020 , the land surface temperature reached minimum values of $26.56^{\circ} \mathrm{C}$ and maximum values of $37.77^{\circ} \mathrm{C}$, with a non-significant decrease in thermal amplitude over time (beta $=0.163, \mathrm{p}=0.562$ ). The average LST is $32.70 \pm 3.29^{\circ} \mathrm{C}$ over the period 1985 2020.

Table 5. State of the land cover from 1988 to 2020

\begin{tabular}{lcccccc}
\hline \multirow{2}{*}{ OCT } & \multicolumn{2}{c}{1988} & \multicolumn{2}{c}{2002} & \multicolumn{2}{c}{2020} \\
\cline { 2 - 7 } & (ha) & $(\%)$ & $($ ha) & $(\%)$ & $($ ha $)$ & $(\%)$ \\
\hline Fd/Fg & 610.42 & 21.42 & 662.17 & 23.24 & 902.29 & 31.59 \\
B_Chr & 138.62 & 4.86 & 11.76 & 0.41 & 25.32 & 0.89 \\
SA/SB & 639.86 & 22.45 & 948.71 & 33.29 & 556.68 & 19.49 \\
Cr_Eau & 176.58 & 6.20 & 107.89 & 3.79 & 204.68 & 7.17 \\
Sv_Arb & 1094.21 & 38.40 & 966.41 & 33.91 & 457.70 & 16.03 \\
Fx & 30.78 & 1.08 & 76.46 & 2.68 & 311.61 & 10.91 \\
Sv_H/SN/Hbt & 159.27 & 5.59 & 76.36 & 2.68 & 397.60 & 13.92 \\
Total & 2849.74 & 100 & 2849.74 & 100 & 2849.74 & 100 \\
\hline
\end{tabular}




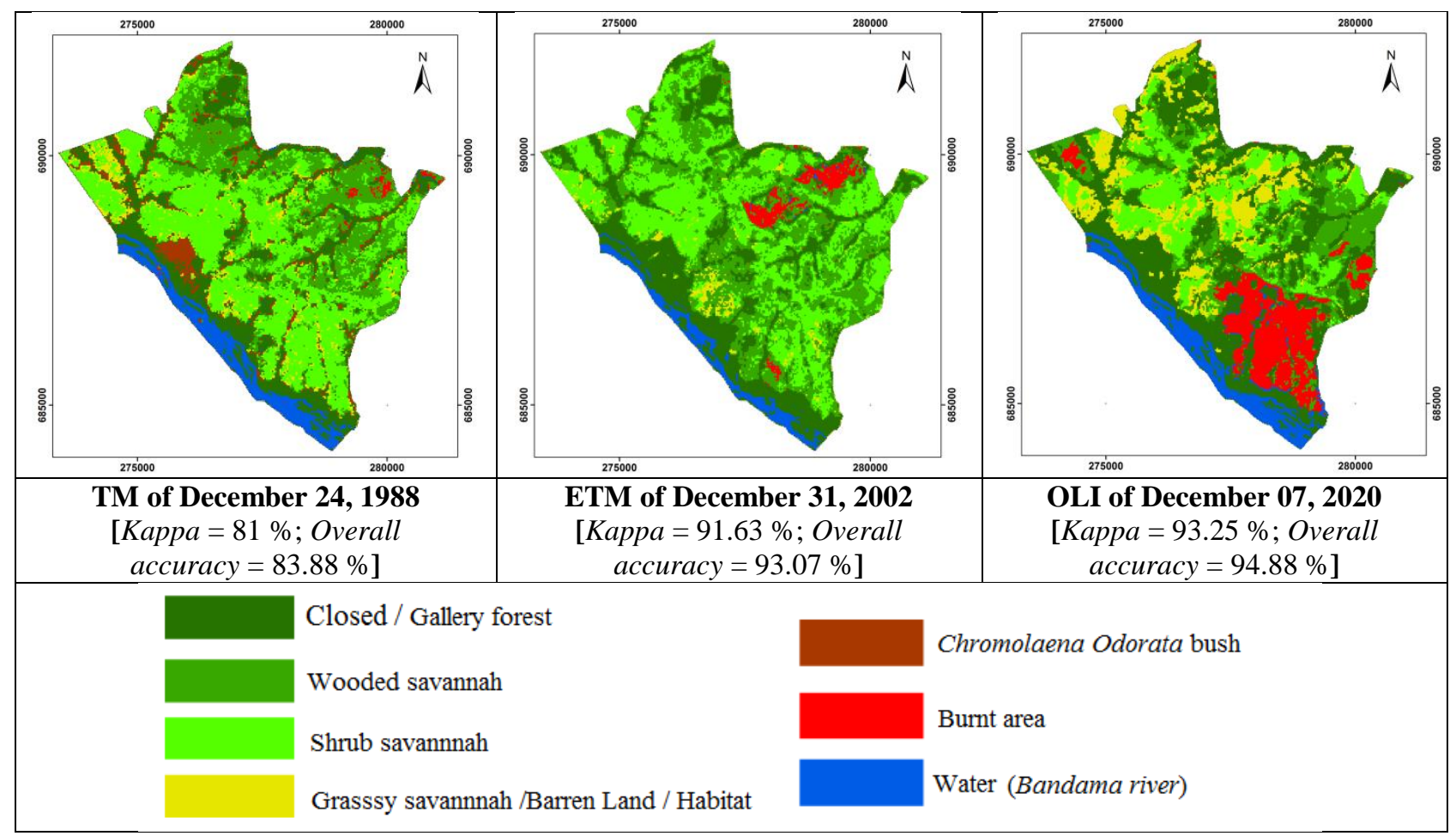

Figure 2. Land cover mapping of Lamto in 1988, 2002 and 2020

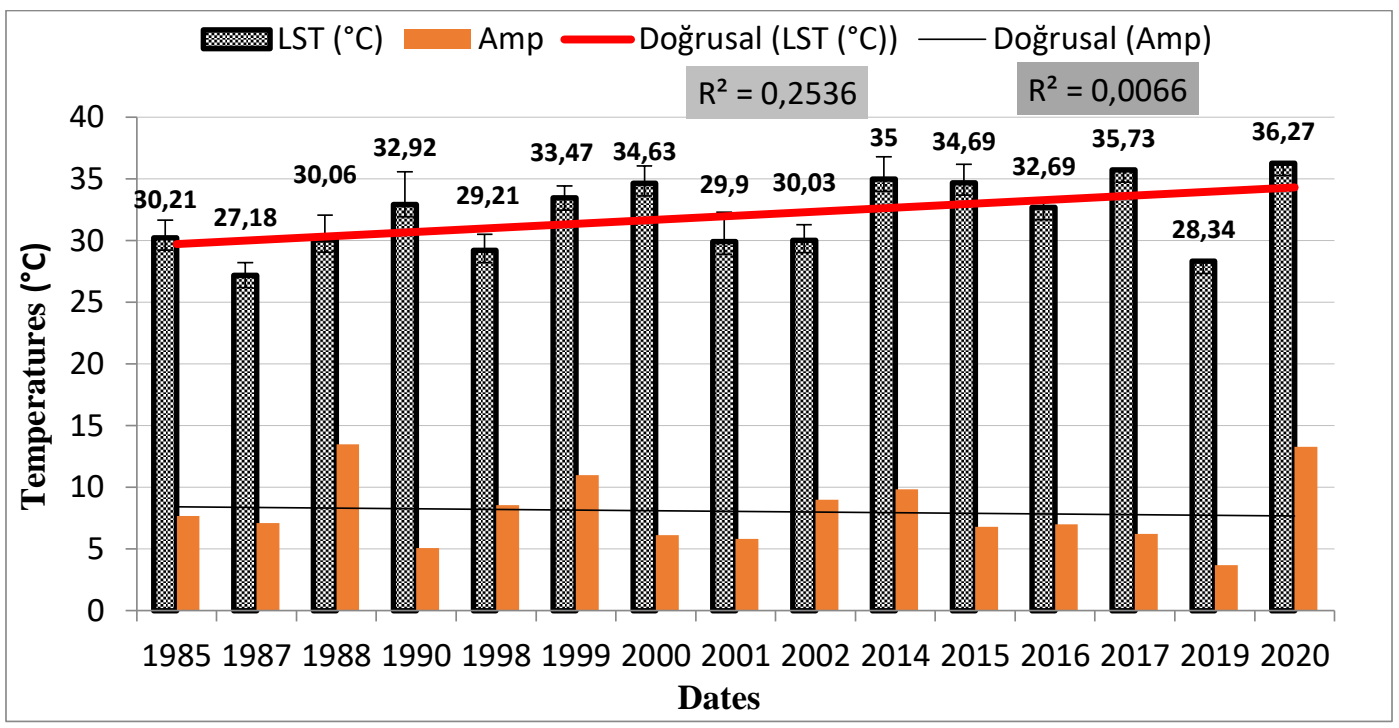

Figure 3. Land Surface Temperature evolution from 1985 to 2020 [LST, Land Surfaces Temperature; Amp, Thermal amplitude]

Temporal evolution of precipitation from 1985 and 2020

The standardized precipitation index (SPI) shows alternating seasonal periods over time (Figure 4). Dry periods are observed from 1985 to 1994 and from 2011 to 2020 . These dry periods have SPI values above -1.5 , resulting in years of near-normal to moderate droughts. In contrast, SPI values are above -1 between 1995 and 2010, characterizing a wet period. In each seasonal period there are very wet years with SPI values above 1.5 (in 1989, for period 1; in 2003 and 2007, for period 2 and, 2015 and 2019, for period 3).

\subsection{Temporal Evolution of Land Surface Temperature and Vegetation Index}

The temporal evolution of Land surface temperature (LST) and vegetation index (NDVI) in Lamto shows a synchronous increase (Figure 5A and 5B). The evolution is very strong with a strong determination $\left(\mathrm{R}^{2}=0.98\right)$ at the LST level (Figure 5A). It increased from $30.46^{\circ} \mathrm{C}$ $\left(1985\right.$ - 1994) to $32.10^{\circ} \mathrm{C}(1995$ - 2010) and then to $34.68^{\circ} \mathrm{C}$ (2011 - 2020). Vegetation index (Figure 5B) initially declined from the first to the second period and gradually increased from the second to the third period. Vegetation index is increasing. It increased from 0.19 (1985 - 1994) to $0.06(1995$ - 2010) and then to 0.24 (2011 - 2020). 


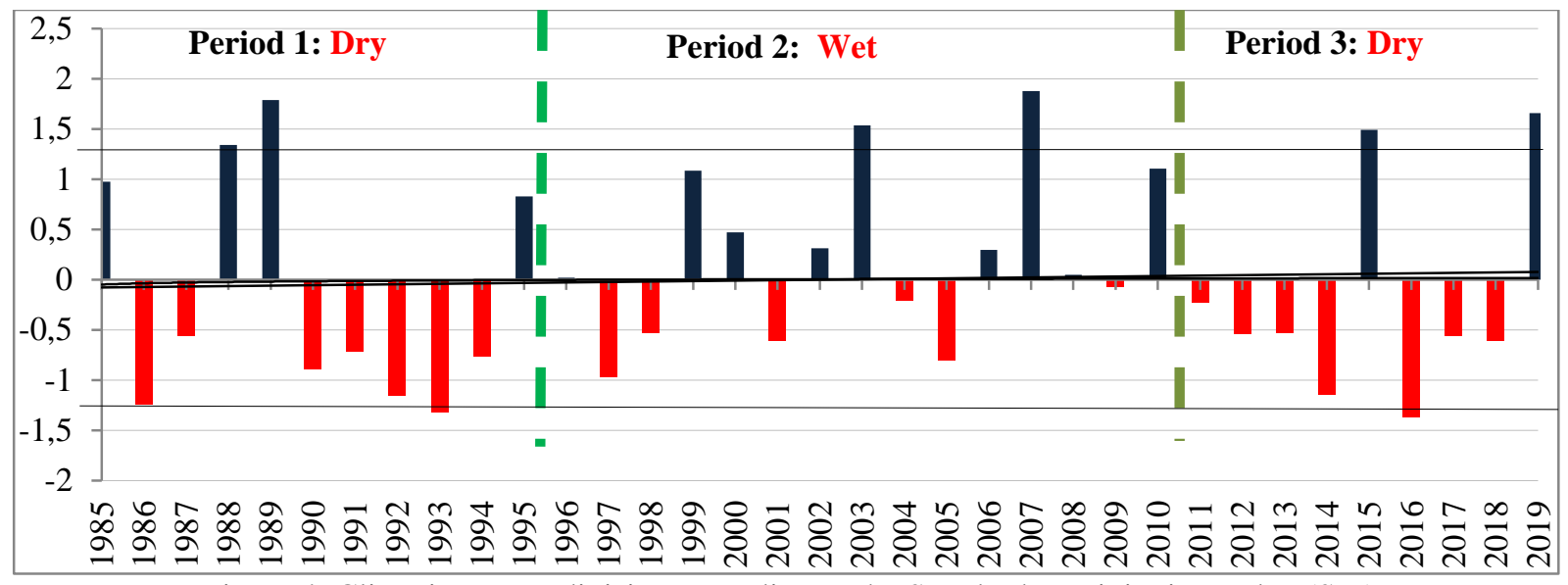

Figure 4: Climatic season division according to the Standard Precipitation Index (SPI)

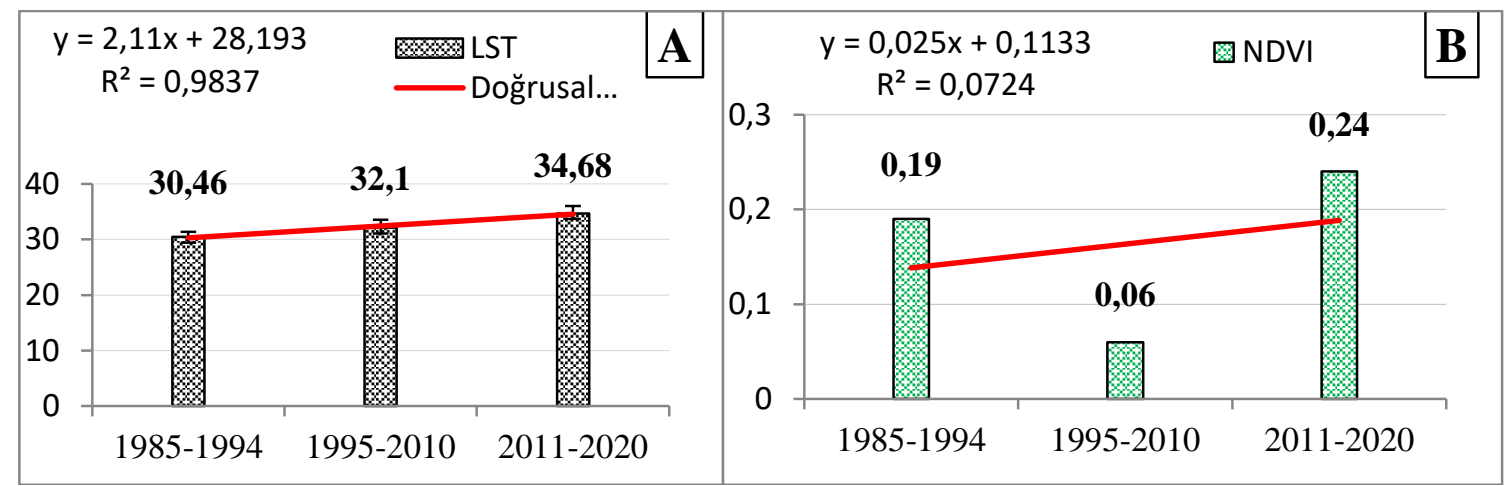

Figure 5. Temporal evolution of the surface temperature $(\mathrm{A})$ and the vegetation index (B)

\subsection{Correlation of Vegetation Index and Land Surface Temperature}

The dynamic relationship between vegetation index (NDVI) and land surface temperature (LST) shows a positive relationship between 1985 and 2020 (Figure 6). This relationship is positive and not significant (NDVI beta $=0.19$, and $p=0.494)$. It appears that vegetation index increases with increasing LST.

Only two land surface temperature (LST) classes are above the average threshold of $32.7^{\circ} \mathrm{C}$ during the period 1985-1994, compared to three and four classes respectively from 1995-2010 and 2011-2020 (Figure 7).
The class increase above the average LST threshold shows the spatial dominance of Lamto land cover warming. Moreover, this warming reaches the closed forests/galleries between 2011 and 2020. At the same time, the maximum vegetation index (NDVI) is reached in the closed forests or Gallery Forests. These maximum index values are $0.32,0.30$ and 0.35 out of an average of 0.16 , for the periods 1985 to 1994,1995 to 2010 and 2011 to 2020 respectively. Only the period from 1995 to 2010 shows negative minimum index values, reflecting very low vegetation index.

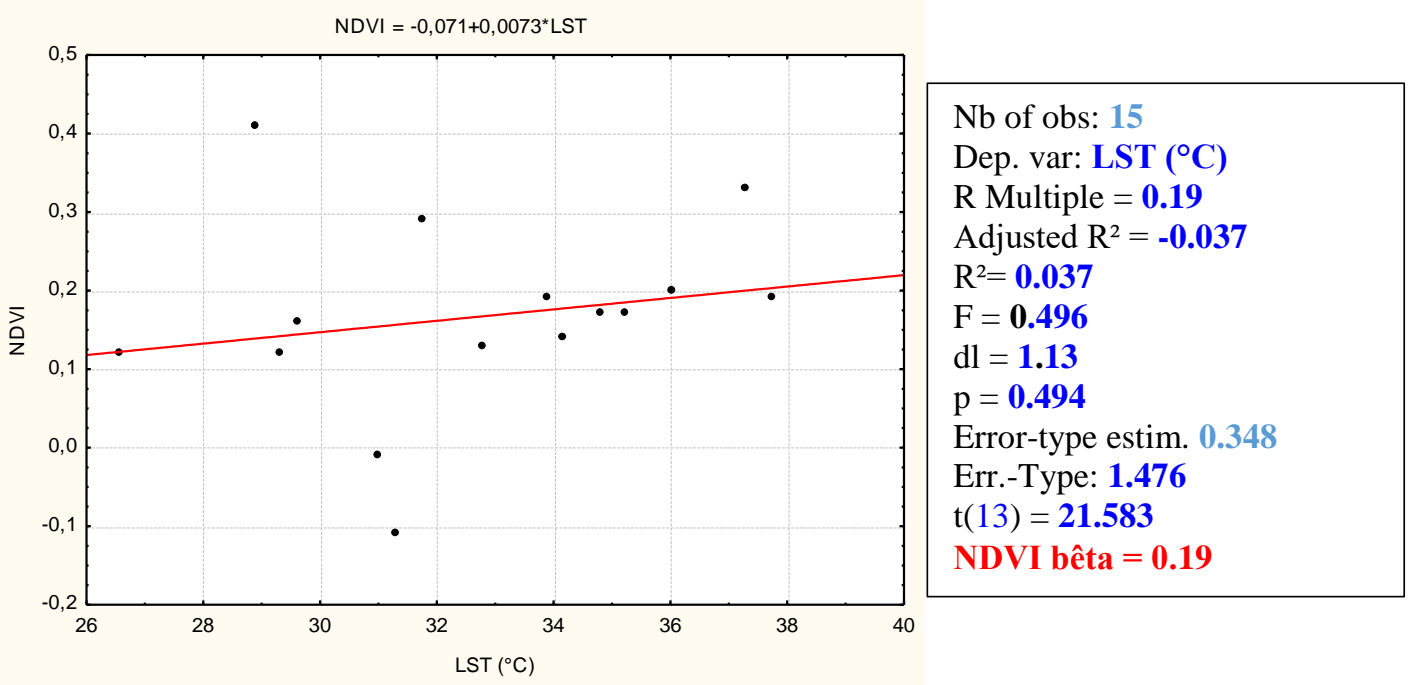

Figure 6. Relation between the Land cover vegetation index and the surface temperature from 1985 to 2020. 


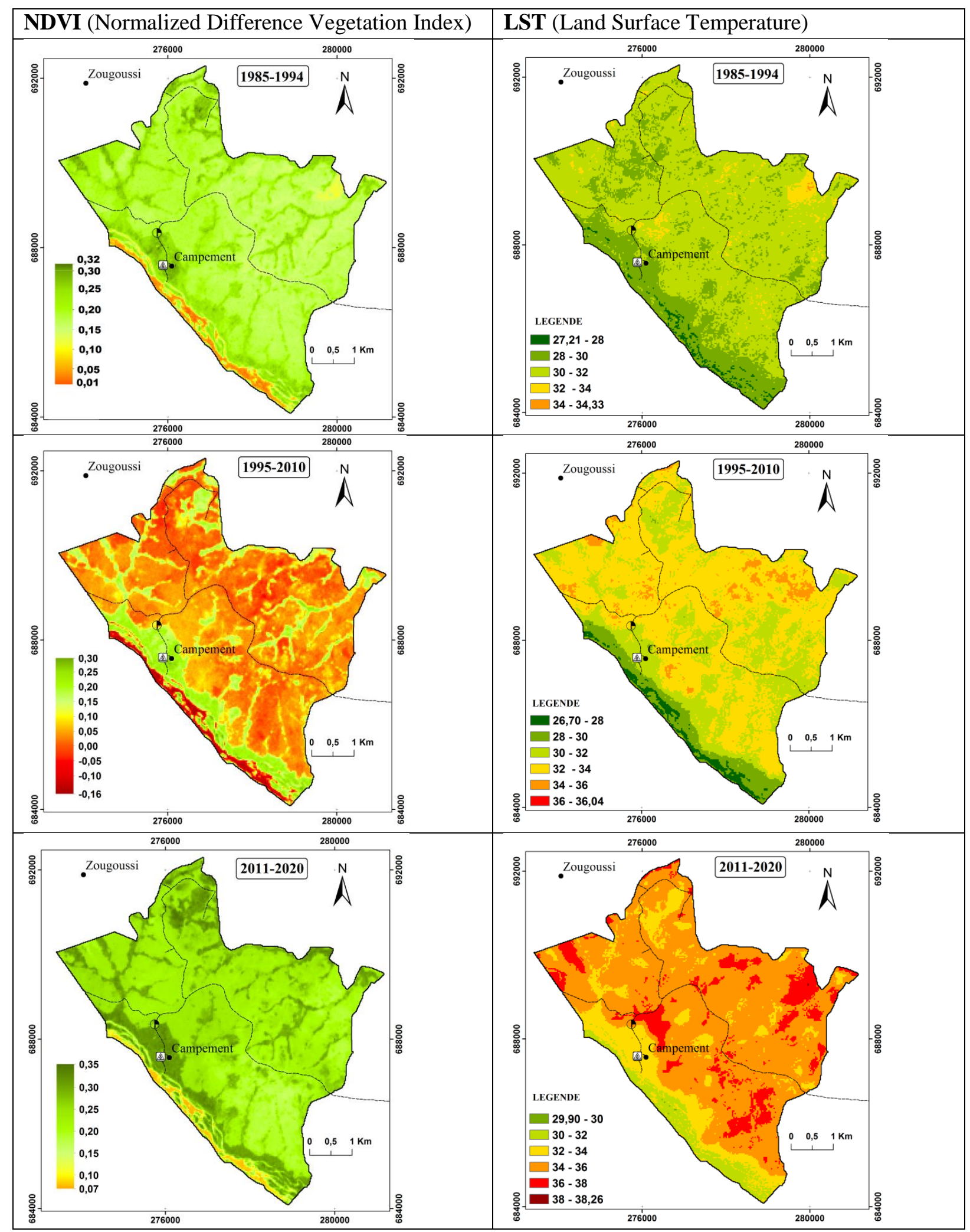

Figure 7.Vegetation index and the land temperature of surface dynamics mapping

\subsection{Response of Land Use to Surface Temperature}

The land cover response of Lamto is shown in Figure 8. It shows that apart from the Land Surface Temperature of shrubby savannahs (Sv_Arb) and burnt areas (Fx), that of the land cover in 1988 and 2002 remained below the average threshold from 1985 to $2020\left(32.70^{\circ} \mathrm{C}\right)$. These are closed or gallery forests $(\mathrm{Fd} / \mathrm{Fdg})$, Chromolaena odorata bushes (B_Chr), wooded savannahs or woody savannahs (SA/SB), grassy areas, bare soils and habitats $\left(\mathrm{Sv} \_\mathrm{H} / \mathrm{SN} / \mathrm{Hbt}\right)$ and even watercourses (Cr_Eau). The temperature of the land cover in 2020 shows an increase, above the average $\left(32.70^{\circ} \mathrm{C}\right)$. 


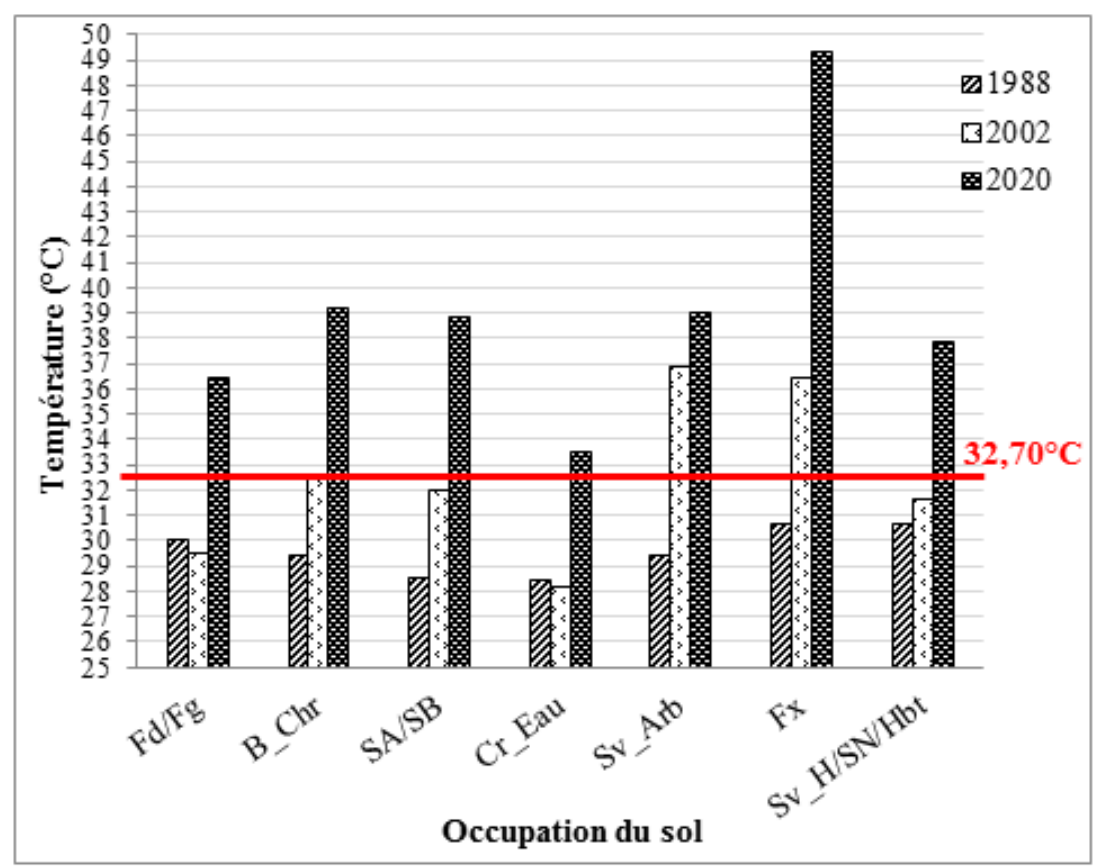

Figure 8. Response of the land cover (LC) to the land surface temperature

\section{Discussion}

Forest dynamics mapping of the Lamto reserve shows an increase in area of 291.87 ha in 32 years (1988 to 2020). This increase is mainly due to the extension of existing forests on pioneer fronts (Koulibaly et al., 2016), rather than to the appearance of new forests in the savannah. The afforestation in Lamto, despite burning, shows the role of bushfires in the natural regeneration cycle of both savannah and forest vegetation. A forest reconquest follows protection against fire and supports the pyroclimax theory according to which fire maintains the savannah (N'Dri et al., 2012) and thus prevents afforestation in the savannah. This forests regeneration would prove that the forest-savannah transition ecosystem would lean towards a forest climax, as opposed to savanization. A trend towards savanization at the expense of afforestation has recently been reported in the Sudanian savannahs of Côte d'Ivoire (Coulibaly et al., 2016) and in the Guinean forest-savannah mosaic of West Africa (Liu et al., 2017).

Lamto vegetation index increases with Land Surface Temperature (LST) between 1985 and 2020. This trend would seem to contradict that obtained by Douffi (2020) over the period 1988 to 2015, with three image data from Landsat TM 1988, ETM 2002 and OLI/TIRS 2015. This difference could be explained by the use of a temporal scale, rather than a spatial (point) scale. At spatial scale, vegetation index increases with decreasing LST (Anbazhagan and Paramasivam, 2016; Haylemariyam, 2018; Douffi, 2020; NourEldeen et al., 2020). The temperature increase in Lamto is in a global context of warming or climate variability. Projections indicate an increase in LST during the 21st century (GIEC, 2014). Climate variability at Lamto has been attributed to the West African monsoon circulation (Diawara et al., 2014). The rate of decrease and increase in rainfall over time describes the seasonal periodicity of rainfall.
Analysis of the Standardised Precipitation Index (SPI) showed a triachronic division of the seasons over time. This could be explained by climatic variability. An interannual variation attributable to climate variability and change as reported in global reports in general and on West Africa in particular (Cassou and Guilyardi, 2007; GIEC, 2014). A decrease in West African regional precipitation is attributed to the strong presence of aerosol in the local monsoon system (Huang et al., 2009). Furthermore, a past dry period decreases vegetation index in the following period, and conversely, a previously wet period increases vegetation index in the following years. However, the distribution of West African biotopes is strongly dependent on soil water resources (rainfall offsets), with successions of dry and wet phases leading to interannual stability of the vegetation index (Do, 2014).

The response of the vegetation dynamics to the increase in Land Surface Temperature (LST) shows that the temperature of the land cover is below the average $\operatorname{LST}\left(32.70^{\circ} \mathrm{C}\right)$ in 1988 and in 2002 . This indicates the maintenance of the pre-2002 microclimate by forest and woodland formations. In 2020, the response of the vegetation dynamics to the LST shows that the land cover temperature is above the mean LST $\left(32.70^{\circ} \mathrm{C}\right)$. This temperature increase on a temporal scale can be explained by the strong presence of savannah ecosystems rather than forests in this ecological transition environment. In general, afforestation cools the surface in tropical areas, but warms boreal lands (Arora and Montenegro, 2011), such as wooded to grassy savannahs. The maximum LST is obtained in burnt areas. This value could reveal the disturbance of the microclimate of the whole land cover including the forest formations by the burning of the savannah of internal or external origin. 


\section{Conclusions}

The temporal analysis of the forest dynamics of Lamto Reserve shows an increase of 291.87 ha in 32 years, with an estimated forest area of 610.42 ha (21.42\%) in 1988 to 662.17 ha (23.24\%) in 2002 and 902.29 ha $(31.59 \%)$ in 2020. Land use changes lead to afforestation. The Land surface temperature characterization indicates an increase from $30.46^{\circ} \mathrm{C}$ to $34.68^{\circ} \mathrm{C}$ in the time trends from 1985 to 2020 . If this thermal increase is not remedied, a future drought with warmer conditions could occur. In addition, the determination of the thermal signatures of land cover can help to provide their roles in contributing to the heat phenomenon. However, the voluntary practice of reserve fires leads to the change of microclimate through the warming of this ecological environment. The land use response to the changing Land Surface Temperature results in a thermal equilibrium. The climate analysis illustrates that forests continue to act as a moderator of the Land Surface Temperature of the reserve. Ultimately, appropriate fire management planning is suggested to mitigate the rise in Land Surface Temperature through policies of anthropogenic actions external or internal to the Lamto reserve on the climate system.

\section{Acknowledgements}

The authors would like to thank the Centre for Ecological Research (CRE) for providing the meteorological data from Lamto. We would also like to thank the United State Geological Survey (USGS) for providing satellite data.

\section{Ethics Committee Approval: N/A.}

Peer-review: Externally peer-reviewed.

Author Contributions: Concept: K.G.C.D.; Design: K.G.C.D.; Supervision: M.K., A.C.Y., K.J.K.; Resources: K.G.C.D.; Data Collection: K.G.C.D. and A.S.T.; Analysis: K.G.C.D.; Literature Search: K.G.C.D.; Writing Manuscript: K.G.C.D. and A.C.Y.; Critical Review: A.C.Y., K.J.K. and M.K.

Conflict of Interest: The authors have no conflicts of interest to declare.

Financial Disclosure: The authors declared that this study has received no financial support

Cite this paper as: Douffi, K.G-C., Yao1, A.C., Koffi, K.J., Traoré, A.S., Koné1, M. 2021. Afforestation in Response to Thermal Change in the Forest-Savannah Transition of the Lamto Scientific Reserve, Côte d'Ivoire, European Journal of Forest Engineering, 7(2):45-56.

\section{References}

Aik, D.H.J., Ismail, M.H., and Muharam, F.M. 2020. Land Use/Land Cover Changes and the Relationship with Land Surface Temperature Using Landsat and MODIS Imageries in Cameron Highlands, Malaysia. Land, 9(372), doi:10.3390/land9100372.

Anbazhagan, S., Paramasivam, C.R. 2016. Statistical correlation between Land Surface Temperature (LST) and Vegetation Index (NDVI) using multitemporal Landsat TM data. International Journal of Advanced Earth Science and Engineering 5(1): 333346.

Arora, V.K., Montenegro, A. 2011. Small temperature benefits provided by realistic afforestation efforts. Nat Geosci, 4(8): 514-518.

Barnieh, B.A., Jia, L., Menenti, M., Zhou, J., Zeng, Y. 2020. Mapping Land Use Land Cover Transitions at Different Spatiotemporal Scales in West Africa. Sustainability, 12(8565), doi:10.3390/su12208565.

Barry, A.A., Caesar, J., Klein Tank, A.M.G., Aguilar, E., McSweeney, C., Cyrille, A.M., Nikiema, M.P., Narcisse, K.B., Sima, F., Stafford, G., Touray, L.M., Ayilari-Naa, J.A., Mendes, C.L., Tounkara, M., GarGlahn, E.V.S., Coulibaly, M.S., Dieh, M.F., Mouhaimouni, M., Oyegade, J.A., Samboup, E., Laogbessi, E.T. 2018. West Africa climate extremes and climate change indices. International Journal of Climatology, DOI: 10.1002/joc.5420.

Barsi, J.A., Schott, J.R., Hook, S.J., Raqueno, N.G., Markham, B.L., Radocinski, R.G. 2014. Landsat-8 thermal infrared sensor (TIRS) vicarious radiometric calibration. Remote Sensing 6: 11607-11626.

Buyadi, S.N.A., Mohd, W.M.N.W., Misni, A. 2013. Impact of land use changes on the surface temperature distribution of area surrounding the National Botanic Garden, Shah Alam. Procedia Social and Behavioral Sciences, 101:516 - 525.

Cassou, C., Guilyardi, É. 2007. Modes de variabilité et changement climatique: Synthèse du quatrième rapport d'évaluation du Giec. La Météorologie - $\mathrm{n}^{\circ} 59$ - novembre 2007, 22-30.

Coulibaly, L., Kouassi, K.H., Soro, G.E., Savané, I. 2016. Analyse du processus de savanisation du Nord de la Côte d'Ivoire par télédétection: Cas du département de Ferkessédougou International Journal of Innovation and Applied Studies, 17(1):136-143.

Diawara, A., Yoroba, F., Kouadio, K. Y., Kouassi, K. B., Assamoi, E. M., Diedhiou, A., Assamoi, P. 2014. Climate variability in the soudano-Guinean transition area and it impact on vegetation: the case of yhe Lamto region in Côte d'Ivoire. Advances in Meteorology, 11p. 
Do, T.P.T. 2014. Apport de la télédétection spatiale pour l'étude multiscalaire des interactions climat-surface en Afrique de l'Ouest : Etude du bassin verssant de Ouémé supérieur (Bénin). Laboratoire d'étude des trransfert en hydrologie et environnement. Doctorat en science de la terre, de l'univers et de l'environnement, $216 \mathrm{p}$.

Douffi, K.G.-C. 2020. Distribution spatiale et dynamique de la population de palmiers rôniers, Borassus aethiopum Mart., par approche de la télédétection et du Système d'Information Géographique (SIG) de la réserve de Lamto (Centre de la Côte d'Ivoire). Biodiversité et Écologie. Université Nangui Abrogoua, Abidjan (Côte d'Ivoire), 2020. Français. $\langle$ tel-03293386v1〉

Douffi, K.G.-C., Koné, M., Kouassi, K.I., N'Guessan, Y. J., Bakayoko, A. 2019. Farmers Establishment Impact on the Forest Dynamic of Monogaga Protected Forest, in the Southwest of Côte d'Ivoire: Remote Sensing and Geographical Information Systems (GIS) Approach. European Journal of Engineering Research and Science, 4(5): 12-20.

Douffi, K.G.-C., Koné, M., Traoré, A.S., Kouakou, A.A. F., N'guessan, J. 2018. Influence des facteurs environnementaux sur la structure spatiale du peuplement rôniers (Borassus aethiopum Mart.) de la savane, au Centre de la Côte d'Ivoire. International Journal of Engineering Science Invention, 7(6): 4056

Gessner, U., Knauer, K., Kuenzer, C., Dech, S. 2015. Land surface phenology in a West African Savanna: impact of land use, land cover and fire. In Remote Sensing Time Series, 203-223. Springer, Cham.

GIEC. 2014. Changements climatiques 2014: Rapport de synthèse. Contribution des Groupes de travail I, II et III au cinquième Rapport d'évaluation du Groupe d'experts intergouvernemental sur l'évolution du climat [Sous la direction de l'équipe de rédaction principale, R.K. Pachauri et L.A. Meyer]. GIEC, Genève, Suisse, $161 \mathrm{p}$.

Haylemariyam, M.B. 2018. Detection of Land Surface Temperature in Relation to Land Use Land Cover Change: Dire Dawa City, Ethiopia. J Remote Sens GIS 7: 245. doi:10.4172/2469-4134.1000245.

Hepner, G.F. 1990. Artificial Neural Network Classification Using a Minimal Training Set: Comparison to Conventional Supervised Classification. Photogrammetric Engineering and Remote Sensing, 56(4): 469-473.

Huang, J., Zhang, C., Prospero, J. M. 2009. African aerosol and large-scale precipitation variability over West Africa. Environmental Research Letter, 4, 015006 (8pp). doi:10.1088/1748-9326/4/1/015006.

Jofack Sokeng, V.-C., Kouamé, F.K., Dibi N'da, H., Tankoano, B., Akpa You, L., Ngounou Ngatcha, B. 2016. Cartographie de l'occupation de sol des Hauts Plateaux de l'Ouest Cameroun par réseaux de neurones appliqués à une image LANDSAT 8 OLI.
International Journal of Innovation and Scientific Research, 23(2): 443-454.

Kouamé, K.R., Dibi Kangah, P.A., Koli Bi, Z. 2019. Variabilité climatique dans le centre-est de la Côte d'Ivoire : indicateurs, scénarii actuels et futurs. Revue de Géographie Tropicale et d'Environnement, 1:720.

Koulibaly, A., Kouamé, D., Groga, N., Kouassi, K.E., Bakayoko, A., Porembski, S. 2016. Floristic characteristics of the mosaic and how forest progress on savanna in the Lamto reserve region (Côte d'Ivoire)? International Journal of Development Research, 6(5): 7792-7799.

Liu, Z., Wimberly, M.C., Dwomoh, F.K. 2017. Vegetation Dynamics in the Upper Guinean Forest Region of West Africa from 2001 to 2015. Remote Sensing, 9(5), doi:10.3390/rs9010005.

Mckee, T.B., Doedken, N.J., Kleist, J. 1993. The relationship of drought frequency and duration to time scales. In Proceedings of the 8th Conference on Applied Climatology, Vol. 17(22): 179-183). Boston , MA: American Meteorological Society.

Mobio, A.B.H., Dré, K.F., Kouamé, A.K.D., Djagoua, M.E.V., Affian, K. 2017. Contribution De La Télédétection A L'étude De La Distribution Spatiale De La Température En Fonction Du Relief Et Du Mode D'occupation Du Sol : Cas De La Ville d'Abidjan (Côte d'Ivoire). International Journal of Engineering Science Invention, 6(12): 48-55.

Morshed, S.R., Fattah, M.A., Rimi, A.A., Haque, M.N. 2020. Surface temperature dynamics in response to land cover transformation. Journal of Civil Engineering, Science and Technology, 11(2).

N'Datchoh, E.T., Konaré, A., Diedhiou, A., Diawara, A., Quansah, E., Assamoi, P. 2015. Effects of climate variability on savannah fire regimes in West Africa. Earth Syst. Dynam., 6, 161-174. doi:10.5194/esd-6161-2015.

N'Dri, A.B., Gignoux, J., Dembele, A., Konate, S. 2012. Short term effects of fire intensity and fire regime on vegetation dynamic in a tropical humid savanna (Lamto, central Côte d'Ivoire) Natural Science, 4(12): 1056-1064.

Ndossi, I.M., Avdan, U. 2016. Application of open source coding technologies in the production of land surface temperature (LST) maps from Landsat: a PyQGIS plugin. Remote sensing, 8(5):413.

NourEldeen, N., Mao, K., Yuan, Z., Shen, X., Xu, T., Qin, Z. 2020. Analysis of the Spatiotemporal Change in Land Surface Temperature for a Long Term Sequence in Africa (2003-2017).

Remote Sensing, 12, 488. doi:10.3390/rs12030488.

Odindi, J.O., Nongebeza, S., Siro, N. 2020. The influence of seasonal land-use-land-cover transformation on thermal characteristics within the city of Pietermaritzburg. South African Journal of Geomatics, 9(2):348-360. DOI: http://dx.doi.org/ 10.4314/sajg.v9i2.23. 
OIPR, 2021. Office Ivoirien des Parcs et Réserves : Reserve de Lamto. Consulté le 04/10/2021, Disponible sur https://www.oipr.ci/index.php/parcsreserves/reserves-naturelles/reserve-de-lamto.

Oguz, H. 2013. LST calculator: A program for retrieving Land Surface Temperature from Landsat TM/ETM+imagery. Environmental Engineering and Management Journal, 12(3): 549-555.

Pontius, R. G. 2000. Quantification error versus location in comparison of categorical maps. Photogrammetric Engineering and Remote Sensing, 66(8): 1011 - 1016. Qin, Z., Karnieli, A., Berliner, P. 2001. A monowindow algorithm for retrieving land surface temperature from Landsat TM data and its application to the Israel-Egypt border region. International Journal of Remote sensing, 22(18): 3719 - 3746.

Sekertekin, A., Kutoglu, S.H., Kaya, S., Marangoz, A.M. 2015. Analysing the effects of different land cover types on land surface temperature using satellite data. Remote Sensing \& Photogrammetry, International Conference on Sensors \& Models in Remote Sensing \& Photogrammetry, 23-25 Nov 2015, Kish Island, Iran.
Setturu, B., Rajan, K.S., Ramachandra, T.V. 2013. Land Surface Temperature Responses to Land Use Land Cover Dynamics. Geoinformatics \& Geostatistics: An Overview, 1(4), http://dx.doi.org/10.4172/23274581.1000112.

Tomlinson, C.J., Chapman, L., Thornes, J.E., Baker, C. 2011. Remote sensing land surface temperature for meteorology and climatology: a review. Meteorological Applications, 18, 296-306. DOI: $10.1002 /$ met.287.

USGS. 2014. Using the USGS Landsat 8 Product. Available online http://landsat.usgs.gov/Landsat8_Using_Product.php (accessed on 9 November 2014).

Vlassova, L., Pérez-Cabello, F. 2016. Effects of post-fire wood management strategies on vegetation recovery and land surface temperature (LST) estimated from Landsat images. International Journal of Applied Earth Observation and Geoinformation, 44: 171-183. http://dx.doi.org/10.1016/j.jag.2015.08.011.

Zhang, J., Wang, Y., Li, Y. 2006. A C++ program for retrieving land surface temperature from the data of landsat TM/ETM+ band 6. Comput. Geosci., 32: 1796-1805. 